\title{
TIME SINCE DEAHT ESTIMATION BY THE METHOD OF THE THREE- DIMENSIONAL-FREQUENCY POLARIZING MAPING FILTERING OF POLYCRYSTALLINE CEREBRO-SPINAL FLUID FILMS IMAGES
}

\author{
M. S. Garazdiuk
}

There are many new methods ware researched in recent years for time since death estimation and laser polarimetric techniques are one of the most perspectiv of them. Thay have demonstrated the high accuracy and objectivity of biological tissue investigation for various intervals of post-mortem period.

The purpose of the work. The post-mortem interval establishment by statistical analysis of the dynamics changes of coordinate distributions of values polarization azimuth (PA) of the polycrystalline films of liquor (PFL) using the three-dimensional-frequency filtering method of biological multiscale layers investigation.

Materials and methods. Objects of investigation are PFL, taken in 67 corpses with accurately known time of death and 6 healthy volunteers. Coordinate distributions of PA image values were estimated for each sample of PFL in the optical arrangement of the Stokes polarimeter using the method of two-dimensional distributions of Stokes-parameters measurement. The value of statistical points of the 1 - 4 th order was perfomed for each two-dimensional distribution of PFL images PE values. Statistical processing of the calculated values of set of points that characterize the PA distributions within representative sampling was carry out. The depending on the time change of the most sensitive points of statistical values were built to achieve values stabilization.

Results and conclusions. Optimal interval in 30 hours and the accuracy of the time since death determination 80 min for the large-scale component of polycrystalline films of liquor and optimal interval in 14 hours and the accuracy of the time since death determination $30 \mathrm{~min}$ for the small -scale component of polycrystalline films of liquor were established by the method of twodimensional Stokes-polarimetric mapping of liquor images polarization azimuth values distribution.

Key words: post - mortem interval, cerebro-spinal fluid, lazer polarimetry.

УДК 616-06:616-079.66:122:167.7

\section{МОЖЛИВОСТІ ОБ'ЄКТИВІЗАЦІї ПАРАМЕТРІВ ТРАВМ ЩЕЛЕПНО-ЛИЦЕВОЇ ДІЛЯНКИ}

\author{
СБрехлічук П. П. ${ }^{1}$, Костенко Є. Я. ${ }^{2}$, Гончарук-Хомин М. Ю. ${ }^{3}$ \\ Кафедра хірургічної стоматології, щелепно-лицевої хірургії та онкостоматології, \\ стоматологічний факультет, ДВНЗ «Ужгородський національний університет»" \\ Кафедра ортопедичної стоматології стоматологічний факультет, \\ ДВНЗ «Ужгородський національний університет»² \\ Науково-навчальний центру судової стоматології стоматологічний \\ факультет, ДВНЗ «Ужгородський національний університет»³
}

Резюме. Згідно даних досліджень різних років поширеність травм щелепно-лицевої ділянки при дорожньо-транспортних пригодах варіює від 17\% до 94\%. Більшість постраждалих у ДТП з травмами щелепно-лицевої області мають комбіновану травму (61\%), і менше половини - ізольовану. 3 метою адекватної реабілітації хворих після ДТП $з$ травмами зубо-щелепового апарату проводиться комплексне медичне лікування, яке у 77\% випадків носить характер хірургічного ятрогенного втручання. Однак, в ході проведеного аналізу існуючих методик оцінки ушкоджень щелепно-лицевої ділянки було встановлено, що у більшості таких підходів не враховуються функціональні порушення зубо-щелепового апарату, що виникають в результаті ураження, відповідно факт реєстрації травми, як і прогноз реабілітації в подібних випадках базується лиш на анатомічному критерії, який не завжди забезпечує відповідний рівень об' єктивності в ході оцінки наслідків дорожньотранспортних пригод. Найбільш перспективний алгоритм оцінки важкості травм максило-фацилярної області $з$ врахуванням параметрів анатомічних та функціональних порушень за системою MFISS обмежений відсутністю уніфікованого підходу до діагностики різних видів травм зубо-щелепового апарату, особливостями механізму формування переломів ЩЛД в результаті ДТП, прив'язаністю до критеріїв AIS-90 як базового параметру оцінки, та помилками верифікації патологічних змін стоматологічного статусу ще на етапі первинної діагностики потерпілих, відтак пошук та розробка оптимального методу оцінки травм зубо-щелепового апарату з метою використання його в ході судово-медичних та судово-стоматологічних експертиз залишається відкритим науково-практичним питанням сучасної стоматології та судової медицини.

Ключові слова: травми щелепно-лицевої області, дорожньо-транспортні пригоди.

ВСТУП. Статистика випадків дорожньо-транспортних пригод, що за даними Українського медичного центру безпеки дорожнього руху та інформаційних технологій Міністерства охорони здоров'я України, за звітний період 2015 р. становить 134193, демонструє, що майже кожен шостий випадок ДТП відбувається з фактом загибелі або травмування потерпілих різного ступеня важкості $[1,1018,19]$. Згідно даних досліджень різних років поширеність травм щелепно-лицевої ділянки при дорожньо-транспортних пригодах варіює від 17\% до 94\% 3 превалеюючою часткою переломів нижньої щелепи (50\%) та майже 3 п'ятою частиною суміжних переломів щелеп [20-22]. Варіативність епідеміологічного профілю травм лицевого скелету та оточуючих м'яких тканин при ДТП залежить від топографії ураженої ділянки, часу та адекватності реєстрації ушкоджень на первиному етапі 
діагностики $[1,11,25,27]$. У інформаційному бюлетені ВООЗ №358 від жовтня 2105 року присвяченому дорожньо-транспортному травматизму вказано, що більше 90\% смертності в ході ДТП припадає на країни з низьким та середнім рівнем соціального забезпечення громадян, а відшкодування та втрати пов'язані з травмами отриманими в ході подібних випадків становлять близько $3 \%$ від валового національного продукту. Відтак проблематика поширеності випадків ДТП носить не тільки медичний, а й соціально-економічний характер. Більшість постраждалих у ДТП з травмами ЩЛД мають комбіновану травму (61\%), і менше половини - ізольовану [6, 7 , 11]. Відповідно з метою адекватної реабілітації проводиться комплексне медичне лікування, яке у $77 \%$ випадків носить характер хірургічного ятрогенного втручання $[18,19]$. Плевинскис П.В. (2014) вказує, що за останній час вимоги до якості проведення комплексних судово-медичних експертиз випадків ДТП значно зросли та потребують підвищення якості та об’єктивності подачі існуючої інформації кожної із сторін-учасників з метою реалізації відповідного захисту як на етапі судового розгляду, так і на етапі досудового слідства $[25,28]$. Розбір механізму формування специфічних видів травм у кожного з пасажирів транспортного засобу в момент ДТП, особливо в області щелепо-лицевої ділянки, повинен включати не тільки аналіз морфологічних особливостей конкретних характеристик ушкоджень, а й специфічні аспекти транспортно-трасологічних причинно-наслідкових зв'язків і судово-стоматологічних аспектів оцінки важкості та перспектив реабілітації з врахуванням індивідуальних особливостей кожної окремої ситуації.

Мета дослідження: проаналізувати існуючі підходи до кількісної оцінки травм щелепно-лицевої ділянки, отриманих в результаті дорожньо-транспортних пригод, та ефективність їх застосування, виходячи із оригінальної методології досліджень; апробувати алгоритм оцінки важкості травм максило-фацилярної області з врахування параметрів анатомічних та функціональних порушень.

Матеріали та методи дослідження. В якості досліджуваного матеріалу використовувались офіційні статистичні дані щодо поширеності випадків ДТП на території України та результати відповідних наукових досліджень представлені у відкритому доступі наукових баз та пошукових систем. Вибірка пацієнтів для апробації підходу оцінки важкості травм максило-фацилярної області з врахування параметрів анатомічних та функціональних порушень проводилась по факту реєстрації травм на базі Ужгородської центральної міської клінічної лікарні з подальшим лікуванням та моніторингом хворих на базі Університетської стоматологічної поліклініки стоматологічного факультету ДВНЗ «УжНУ». Діагностика пацієнтів проводилась згідно протоколі надання стоматологічної допомоги населенню затверджених МОЗ України з виконанням відповідних рентгенологічних досліджень за показами. 3 метою детальної верифікації поширеності уражень проводились уточнюючі рентгенологічні дослідження (планіметричні у різних проекціях та конусно-променева комп'ютерна томографія), що дозволили чітко розділити усі випадки на такі, в яких спостерігались ізольовані переломи верхньої щелепи, ізольовані переломи нижньої щелепи, ізольовані переломи виличного комплексу та поєднані переломи щелепно-лицевої області В ході цільового формування вибірки було відібрано 73 випадки травм максило-фацилярної області пацієнтів віком 23-57 років різної статі. Оцінка важкості травм максило-фацилярної області групи вибірки проводилась з врахування параметрів анатомічних та функціональних порушень за формулою MFISS = $(\mathrm{A} 1+\mathrm{A} 2+\mathrm{A} 3)^{*}(\mathrm{MO}+\mathrm{LMO}+\mathrm{FD})$, де A1, A2, A3 - показники оцінки за AIS-90, MO (malocclusion) - порушення оклюзії, LMO (limited mouth opening) - обмежене відкривання рота, FD (facial deformaties) - деформації обличчя, згідно методики запропонованої Zhang та колегами. Аналіз літературних джерел проводився згідно принципів реалізації контент-аналізу текстового матеріалу з формуванням відповідних категорій аналізу та систематизацією чисельних даних.

\section{РЕЗУЛЬТАТИ ДОСЛІДЖЕННЯ ТА ЇХ ОБГОВОРЕННЯ.}

Проблематика особливостей травматизму постраждалих в момент ДТП була широко розглянута у роботах вітчизняних та зарубіжних дослідників, які враховували не тільки особливості реабілітації потерпілих, а й були спрямовані на розробку специфічних алгоритмів для реєстрації позиції пасажирів у транспортному засобі $з$ метою встановлення вектору ударно-інерційних переміщень, верифікації травмонебезпечності деталей салону відносно кожного з пасажирів, аналіз механізмів формування травм, побудову прямих причиннонаслідкових зв'язків комплексної експертизи $[1,3,6,23-28]$. В ході аналізу причинно-наслідкових зв'язків виникнення травм в умовах ДТП було доведено, що ризик травматизму корелює із позицією особи у транспортному засобі. Так, переломи кісток лицевого скелету найчастіше виникають саме у водіїв та пасажирів на передньому сидінні автомобіля, в той час, як ушкодження м'яких тканин широко зустрічаються і серед пасажирів позаду водія $[1,11,23,28]$. Аналогічна тенденція спостерігається і серед пішоходів-учасників ДТП: ризик виникнення перелому кісток ЩЛД апарату у них не перевищує 11-16\%, в той час як травми м'яких тканин обличчя спостерігаються майже втричі частіше згідно результатів ретроспективного аналіз зарубіжних джерел [3, 6, 7]. Крім того, в ході аналізу проведено Alvi А. та колегами (2003), було встановлено, що важливе значення має не тільки факт діагностики травми щелепно-лицевої ділянки, а й можливість вчасної верифікації поєднаних з нею травм [2]. Встановивши, що найбільш поширеними причинами травм області обличчя були випадки фізичного насилля та факти ДТП, авторам вдалось визначити, що найбільш часто з подібними ураженнями поєднуються 
церебральні травми - ураження голови спостерігались у 5,4-85\% випадків, та легеневі порушення, ускладнення від яких виникали в 50,3-60,5\% випадків. При цьому Eid H.О. та колегам (2009) вдалось підтвердити на вибірці із 1070 пацієнтів - потерпілих ДТП, що факт ушкодження області голови найбільш асоційований з показником смертності осіб, при цьому поширеність травм щелепно-лицевої ділянки осіб, котрі на момент ДТП знаходилась в автомобілі, сягала майже 30\% [6]. Дослідження Erdmann D. та колег (2008) підтвердили аналогічний розподіл причин травм ЩЛД, також визначивши, що саме факти травми по причині дорожньо-транспортних пригод та в результаті вогнепальних поранень є найбільш небезпечними, та такими, що провокують виникнення критичних ускладнень в майбутньому [7].

Незважаючи на те, що за даними Gassner et al. (2003) адекватна реєстрація травм лицевого скелету з використанням комп'ютерно-томографічних методів візуалізації забезпечує ефективність діагностики більше ніж у 90\% випадків, використанням томографічних методів дослідження спостерігається лише у 69\% випадків на первинному етапі комплексної діагностики, у інших випадках - проведення комп'ютерної томографії носить уточнюючий або ж первинний відстрочений діагностичний характер [8]. 3 врахуванням відповідних можливостей діагностики стає зрозумілим, чому питання розробки підходу до оціни травм щелепо-лицевої області, який би крім констатації об’єктивного стану хворого після факту отримання травми також враховував би і майбутній прогноз реабілітації пацієнта, залишається актуальним у структурі судово-стоматологічної експертизи.

Проблема попередніх підходів до оцінки травм зубо-щелепового апарату полягає у тому, що у більшості 3 них не враховуються функціональні порушення, що виникають в результаті патології, відповідно факт реєстрації травми, як і прогноз реабілітації базується лише на анатомічному критерії, який не завжди забезпечує відповідний рівень об'єктивності в ході оцінки наслідків дорожньо-транспортних пригод. Запропонована American Association for Automobile Medicine Абревіаційна шкала дозволяє встановити важкість спровокованих ушкоджень, однак не враховує прогноз подальшої реабілітації, оскільки калькуляція показника заснована виключено на анатомічній складовій [5]. На основі Injury Severity Score розробленого Baker та колегами [4] додатково було опрацьовано параметр Trauma and Injury Severity Score (TRISS), який враховував уже не тільки анатомічні, а й фізіологічні критерії оцінки, вік пацієнта та механізм утворення травми [13]. Подальша модифікація підходів до оцінки травм передбачає можливість використання таких підходів як New Injury Severity Score (NISS), Severity Characterization of Trauma (ASCOT), Acute Physiology and Chronic Health Evaluation (APACHE), Mortality Probability Models (MPA), при чому останні були розроблені для використання у специфічних медичних відділеннях з врахуванням факту необхідності та об’єму надання термінової медичної допомоги [13-16]. Bargheri S. та колеги (2006) 3 метою налагодження етапів надання медичної допомоги лікарями різних спеціальностей в ході комплексного лікування потерпілого запропонували авторську шкалу Facial Injury Severity Scale (FISS), яка передбачала топографічний поділ зони обличчя на нижню щелепу, середній та верхній відділи [3]. Шкала градації передбачає бальну оцінку відповідних форм ураження: денто-альвеолярні - 1 бал, переломи гілки/тіла/симфізу щелепи - 2 бали, Ле Фор I (II, III) - $2(4,6)$ балів відповідно, зміщення гайморової пазухи - 5 балів і т.д. Даний підхід можна використовувати 3 діагностичною та консультаційною метою, крім того шкала забезпечує можливості для сумації наслідків усіх заподіяних травм з можливістю калькуляції кінцевого показника ураження. Однак не вирішеним залишається питання уніфікації саме діагностичного алгоритму потерпілих, в результатів якого вдалось би встановити результати дії травматичного чинника ще на первинному етапі діагностики. Крім того, FISS у більшій мірі враховує пошкодження твердих тканин лицевого скелету, в той час як ушкодження м'яких тканин в результаті ДТП чи 3 побутових, професійних, спортивних та інших причин також характеризуються значною поширеністю. Хоча в результаті проведених Bargheri S.(2006) досліджень і вдалось встановити значну кореляцію між чисельним показниками FISS та кошторисом надання спеціалізованих медичних послуг, проте аспект взаємозв'язку параметрів тривалості реабілітації та результатів оцінки ушкоджень зубо-щелепового апарату за Facial Injury Severity Scale залишається відкритим і потребує більш деталізованого вивчення на значно більшій досліджуваний вибірці [3]. У тому ж році Gennarelli та Wodzin (2006) провели деталізований аналіз Abbreaviaed Injury Scale (AIS), який забезпечує оцінку важкості травми та встановлює точну їі топографію, кодуючи ураження при цьому за допомогою відповідних локалізаторів [9]. Важкість ураження за AIS визначається за такими параметрами, як небезпека для життя, смертність (теоретична, прогнозована, дійсна, потреба в госпіталізації, вартість лікування, складність лікування, тривалість лікування, тимчасова чи постійна втрата працездатності, незворотний характер порушень, показник якості життя, дисипація енергії, що успішно можуть використовуватись і при оцінці функціональних та анатомічних порушень області щелепо-лицевого апарату.

Враховуючи недоліки усіх вищеперелічених підходів Zhang та колеги у 2006 р. запропонували свою універсальну систему оцінки Maxillofacial Injury Severity Score (MFISS), яка враховувала особливості функціонування та біомеханіки зубо-щелепового апарату як специфічної області тіла людини [17]. Згідно авторського підходу спочатку визначають три найвищі оцінки ураження областей ЩЛд за AIS-90, після чого поєднують їх із наявними у пацієнта ознаками функціонального порушення, що проявляються у зміні оклюзійних співвідношень, обмеженому відкриванні рота і деформації обличчя через формулу: MFISS = $(\mathrm{A} 1+\mathrm{A} 2+\mathrm{A} 3) *(\mathrm{MO}+\mathrm{LMO}+\mathrm{FD})$, де A1, A2, А3 - показники оцінки за AIS-90, MO (malocclusion) - порушення 
оклюзії, LMO (limited mouth opening) - обмежене відкривання рота, FD (facial deformaties) - деформації обличчя. При цьому автори чітко виділили кокретні прояви кожного з функціональних порушень відповідної до бальної системи градації.

Проведений аналіз 73 випадків переломів кісток лицевого скелету, що були відібрані із сукупності усіх випадків травм зареєстрованих на базі Ужгородської центральної міської клінічної лікарні з подальшим лікуванням та моніторингом хворих на базі Університетської стоматологічної поліклініки стоматологічного факультету ДВНЗ «УжНУ» протягом 2016 року, які підлягали топографічним критеріям - переломи верхньої щелепи (26), переломи нижньої щелепи (18), переломи виличного комплексу (16), поєднані переломи щелеполицевої області (13), дозволив встановити, що середні критерії оцінки за системою MFISS складали 20,4; 25,6; 15,6 та 32,7 відповідно для кожного із виду переломів. При цьому значної кореляції між терміном лікування та встановленими показниками серед усіх досліджуваних випадків встановити не вдалось, а рівень такої коливався в межах 0,145-0,254. У дослідженні проведеному Zhang (2006) було відмічено, що кількість днів проведених у лікарні та вартість лікування зростає паралельно із підвищенням показника MFISS, однак така залежність у проведеному раніше дослідженні може бути обгрунтована особливостями надання медичної допомоги пацієнтам в умовах обов'язкового медичного страхування [17]. Хоча Ramalingam S. (2015) підтвердив значимість показників MFISS та FISS як таких, які корелюють із параметрами вартості лікування $(\mathrm{R}=0.862, \mathrm{P}<0.001$ та $\mathrm{R}=0.845, \mathrm{P}$ $<0.01$ відповідно) та терміну госпіталізації $(\mathrm{R}=0.828, \mathrm{P}<0.01$ та $\mathrm{R}=0.819, \mathrm{P}<0.01$ відповідно) [12]. 3 іншої сторони імплементації подібної системи оцінки уражень максило-фацилярної ділянки обмежена існуючими протоколами надання медичної допомоги населенню, відсутністю уніфікованого підходу до діагностики різних видів травм, особливостями механізму формування переломів області ЩЛД в результаті ДТП, прив'язаністю до критеріїв AIS-90 як базового параметру оцінки, та помилками верифікації змін зуба-щелепового апарату на етапі первинної діагностики потерпілих.

ВИСНОВОК. В ході проведеного аналізу було встановлено, що у більшості підходів до оцінки травм максило-фацилярної області не враховуються функціональні порушення зубо-щелепового апарату, що виникають в результаті ДТП, відповідно факт реєстрації травми, як і прогноз реабілітації в подібних випадках базується лиш на анатомічному критерії, який не завжди забезпечує відповідний рівень об'єктивності в ході оцінки наслідків дорожньо-транспортних пригод. Особливості останніх полягають у тому, що розбір механізму формування специфічних видів травм у кожного з пасажирів транспортного засобу в момент ДТП повинен включати не тільки аналіз морфологічних особливостей конкретних характеристик ушкоджень, а й специфічні аспекти транспортнотрасологічних причинно-наслідкових зв'язків і судово-стоматологічних аспектів оцінки важкості та перспектив реабілітації з врахуванням індивідуальних особливостей кожної окремої ситуації. В результаті апробації системи оцінки уражень максило-фацилярної ділянки MFISS, запропонованої Zhang та колегами, виявилось, що вона обмежена існуючими протоколами надання медичної допомоги населенню, відсутністю уніфікованого підходу до діагностики різних видів травм, особливостями механізму формування переломів області ЩЛД в результаті ДТП, прив'язаністю до критеріїв AIS-90 як базового параметру оцінки, та помилками верифікації змін зубо-щелепового апарату на етапі первинної діагностики потерпілих.

\section{Література}

1. Abu-Zidan F. M. Effects of seat belt usage on injury pattern and outcome of vehicle occupants after road traffic collisions: prospective study / Abu-Zidan F. M. et al. //World journal of surgery. - 2012. - T. 36. - №. 2. - C. 255 259.

2. Alvi A. Facial fractures and concomitant injuries in trauma patients / Alvi A., Doherty T., Lewen G. // The Laryngoscope. - 2003. - T. 113. - №. 1. - C. 102-106.

3. Bagheri S. C. Application of a facial injury severity scale in craniomaxillofacial trauma / Bagheri S. C. et al. // Journal of oral and maxillofacial surgery. - 2006. - T. 64. - №. 3. - C. 408-414.

4. Baker S. P. The injury severity score: an update / Baker S. P., O'neill B. //Journal of Trauma and Acute Care Surgery. $-1976 .-$ T. 16. - №. 11. - C. 882-885.

5. Civil I. D. The Abbreviated Injury Scale, 1985 revision: a condensed chart for clinical use / Civil I. D., Schwab C. W. //Journal of trauma. - 1988. - T. 28. - №. 1. - C. 87-90.

6. Eid H. O. Factors affecting anatomical region of injury, severity, and mortality for road trauma in a high-income developing country: lessons for prevention / Eid H. O. et al. //Injury. - 2009. - T. 40. - №. 7. - C. 703-707.

7. Erdmann D. A retrospective analysis of facial fracture etiologies/ Erdmann D. et al. //Annals of plastic surgery. 2008. - T. 60. - №. 4. - C. 398-403.

8. Gassner R. Cranio-maxillofacial trauma: a 10 year review of 9543 cases with 21067 injuries / Gassner R. //Journal of cranio-maxillofacial surgery. - 2003. - T. 31. - №. 1. - C. 51-61. 
9. Gennarelli T. A. AIS 2005: a contemporary injury scale / Gennarelli T. A., Wodzin E. //Injury. - 2006. - T. 37. - №. 12. - C. 1083-1091.

10. http://umcbdr.com.ua/

11. Malara P. Characteristics of maxillofacial injuries resulting from road traffic accidents-a 5 year review of the case records from Department of Maxillofacial Surgery in Katowice, Poland / Malara P., Malara B., Drugacz J. //Head \& face medicine. - 2006. - T. 2. - №. 1. - C. 1.

12. Ramalingam S. Role of maxillofacial trauma scoring systems in determining the economic burden to maxillofacial trauma patients in India / Ramalingam S. //Journal of international oral health: JIOH. - 2015. - T. 7. - №. 4. - C. 38.

13. Schluter P. J. Trauma and injury severity score (TRISS) coefficients 2009 revision / Schluter P. J. et al. //Journal of Trauma and Acute Care Surgery. - 2010. - T. 68. - №. 4. - C. 761-770.

14. Sharma B. R. The injury scale-a valuable tool for forensic documentation of trauma / Sharma B. R. //Journal of clinical forensic medicine. - 2005. - T. 12. - №. 1. - C. 21-28.

15. Stevenson M. An overview of the injury severity score and the new injury severity score / Stevenson M. //Injury Prevention. - 2001. - T. 7. - №. 1. - C. 10-13.

16. Tohira H. Systematic review of predictive performance of injury severity scoring tools / Tohira H.//Scandinavian journal of trauma, resuscitation and emergency medicine. - 2012. - T. 20. - №. 1. - C. 1.

17. Zhang J. Maxillofacial Injury Severity Score: proposal of a new scoring system / Zhang J. //International journal of oral and maxillofacial surgery. - 2006. - T. 35. - №. 2. - C. 109-114.

18. Бичков В. В. Основні напрямки оптимізації надання медичної допомоги постраждалим в дорожньо-транспортних пригодах / Бичков В. В. //Травма. - 2009. - Т. 10. - №. 4.

19. Богдан О. В. Дорожно-транспортный травматизм в современных условиях / Богдан О. В. //Травма. - 2010. T. 11. - №. 2. - C. 123-126.

20. Гоженко А. І. Проблеми виникнення дорожньо-транспортних пригод та дорожньо-транспортного травматизму в Україні. Можливі шляхи їх вирішення/ Гоженко А. І., Біла Ю. С. //Актуальні проблеми транспортної медицини. - 2012. - №. 3. - С. 29.

21. Губайдуллин М. И. Эпидемиология дорожно-транспортных происшествий и транспортного травматизма (обзор отечественной и зарубежной литературы) / Губайдуллин М. И. //Вестник Южно-Уральского государственного университета. Серия: Образование, здравоохранение, физическая культура. - 2010. - №. 19 (195).

22. Джанелидзе И. И. Дорожно-транспортный травматизм как медико-социальная проблема / Джанелидзе И. И. //Скорая медицинская помощь. - 2007. - С. 5.

23. Плевинскис П. В. Возможные варианты комбинированных видов автомобильной травмы/ Плевинскис П. В. //Вісник проблем біології і медицини. - 2016. - №. 1 (1). - С. 392-395.

24. Плевинскис П. В. Исходные данные и алгоритм работы экспертов при проведении комплексных судебномедицинских и транспортно-трассологических экспертиз в случаях наезда автомобиля на пешехода / Плевинскис П. В. //Судово-медична експертиза. - 2013. - №. 2. - С. 8-11.

25. Плевинскис П. В. Некоторые типичные трудности при проведении единоличных судебно-медицинских экспертиз в случаях наезда автомобиля на пешехода со смертельным исходом / Плевинскис П. В. //Судовомедична експертиза. - 2014. - №. 1. - С. 59-62.

26. Плевинскис П. В. Сложные ситуации при установлении местонахождения пострадавших в салоне автомобиля в момент ДТП/ Плевинскис П. В. //Судово-медична експертиза. - 2013. - №. 1. - С. 23-26.

27. Плевинскис П. В. Современный алгоритм подхода к дифференциальной диагностике телесных повреждений у водителей и пассажиров легковых автомобилей в случаях ДТП/ Плевинскис П. В. //Судово-медична експертиза. - 2012. - №. 6. - С. 27-29.

28. Плевинскис П. В. Типичные трудности в ходе назначения и производства первичных судебно-медицинских экспертиз в случаях травмирования пешехода автомобилем со смертельным исходом/ Плевинскис П. В. // Збірник наукових праць співробітників НМАПО ім. ПЛ Шупика. - 2014. - №. 23 (4). - С. 92-99.

\title{
ВОЗМОЖНОСТИ ОБЕКТИВИЗАЦИИ ПАРАМЕТРОВ ТРАВМ ЧЕЛЮСТНО-ЛИЦЕВОЙ ОБЛАСТИ
}

\author{
Брехличук П. П., Костенко Е. Я., Гончарук-Хомин М. Ю.
}

Резюме. Согласно данным исследований разных лет распространенность травм челюстно-лицевой области при дорожно-транспортных происшествиях варьирует от $17 \%$ до 94\%. Большинство пострадавших в ДТП с травмами челюстнолицевой области имеют комбинированную травму (61\%), и меньше половины - изолированную. С целью адекватной реабилитации больных после ДТП с травмами зубочелюстной аппарата проводится комплексное медицинское лечение, которое в 77\% случаев носит характер хирургического ятрогенного вмешательства. Однако, в ходе проведенного анализа существующих методик оценки повреждений челюстно-лицевой области было установлено, что в большинстве таких подходов не учитываются 
функциональные нарушения зубочелюстного аппарата, возникающие в результате поражения, соответственно факт регистрации травмы, как и прогноз реабилитации в подобных случаях базируется лишь на анатомическом критерии, который не всегда обеспечивает соответствующий уровень объективности в ходе оценки последствий дорожно-транспортных происшествий. Наиболее перспективный метод оценки тяжести травм максило-фацилярной области с учетом параметров анатомических и функциональных нарушений по системе MFISS ограничен отсутствием унифицированного подхода к диагностике различных видов травм зубочелюстного аппарата, особенностями механизма формирования переломов ЧЛО в результате ДТП, привязанностью к критериям AIS- 90 в качестве базового параметра оценки, и ошибками верификации патологических изменений стоматологического статуса еще на этапе первичной диагностики пострадавших, поэтому поиск и разработка оптимального метода оценки травм зубочелюстной аппарата с целью использования его в ходе судебно-медицинских и судебно-стоматологических экспертиз остается открытым научно практическим вопросом современной стоматологии и судебной медицины.

Ключевые слова: травмы челюстно-лицевой области, дорожно-транспортные происшествия.

\title{
POSSIBILITIES OF MAXILLOFACIAL INJURY'S PARAMETERS OBJECTIFICATION
}

\author{
Brehlichuk P. P., Kostenko Y. Y., Goncharuk-Khomyn M. Y.
}

Resume. According to the results of different researches, the prevalence of maxillofacial area injuries during road traffic accidents ranges from $17 \%$ to $94 \%$. Most of the victims with maxillofacial region alterations after such accidents have combined injuries $(61 \%)$, and less than half have isolated injuries. In order to provide adequate rehabilitation of such patients with a tooth-jaw apparatus injuries, should be conducted comprehensive medical treatment that in $77 \%$ of cases includes surgical iatrogenic intervention. However, during the analysis of existing methodologies to assess the damages of maxillofacial area, it was found that the most of these approaches didn't capture functional disorders of the teeth-jaw system after road traffic accidents, respectively the registration of injuries in such cases is based only on anatomical criteria, which does not always provide the appropriate level of objectivity during the evaluation of the accidents post effects. The most promising algorithm for assessing the severity of maxillofacial injuries with regard to anatomic and functional changes included in the MFISS system, that is also limited to the lack of a unified approach for the diagnostics of different types of tooth-jaw apparatus injuries, especially to the mechanism of formation of maxillofacial fractures during traffic accident, adherence to the AIS- 90 criteria as a basic estimation parameter and due to the verification errors of dental status lesions at the stage of initial diagnostics of the victims. That is why the research and development of the optimal method for assessing tooth-jaw apparatus injuries that can be used during forensic medical and forensic dental examinations is an open scientific and practical aspect of modern dentistry and forensic medicine.

Key words: injuries maxillofacial area of road accidents.

УДК: $340.62: 616.742-001$

\section{НЕВИПРАВНЕ ЗНІВЕЧЕННЯ ОБЛИЧЧЯ - СУДОВО-МЕДИЧНІ ТА ЮРИДИЧНІ АСПЕКТИ}

\author{
С.Л. Л. Голубович ${ }^{1}$, А. Л. Голубович ${ }^{2}$, П. Л. Голубович ${ }^{2}$, \\ М. Д. Зубко ${ }^{1}$, А. В. Куртєв² \\ Запорізький державний медичний університет ${ }^{1}$ \\ Запорізьке обласне бюро судово-медичної експертизи ${ }^{2}$
}

Резюме. Швидкоплинні зміни в економічному, політичному і суспільному житті диктують потребу змін і у правовій сфері, де працюють не тільки юристи а й судово-медичні експерти, основна робота яких полягає у допомозі судово-слідчим органам у встановленні істини в конкретних справах, коли скоєні злочини проти життя, здоров'я, честі чи гідності людини. В роботі аналізуються труднощі, з якими стикається судово-медичний експерт при визначенні ступеня тяжкості спричинених тілесних ушкоджень за критерієм «невиправне знівечення обличчя» і пропонуються шляхи усунення протиріч.

Ключові слова: судово-медична експертиза, невиправне знівечення обличчя, ступінь тяжкості тілесних ушкоджень

ВСТУП. Найбільш часто судово-медичним експертам доводиться мати справу з потерпілими особами, особливо з приводу спричинення їм тілесних ушкоджень. Цією публікацією ми долучаємося до проблеми піднятої у публікаціях А.Х. Завальнюка зі співавторами $[1,2]$ в яких автори пропонують внесення корективів у існуючи правила кваліфікації тяжкості тілесних ушкоджень.

Судово-медичне визначення ступеня тяжкості спричинених тілесних ушкоджень проводиться згідно 3 Кримінальним та Кримінально-процесуальним кодексами України [3] і Правилами судово-медичного визначення ступеня тяжкості тілесних ушкоджень [4]. На жаль ці правила не відрізняються читкістю формулювань і однозначністю трактувань характеристик тих чи інших критеріїв.

Особливо це стало помітним після прийняття «Закону України про адвокатуру та адвокатську діяльність» [5] (поточна редакція від 06. 02.2015p) та останнього редагування Кримінально процесуального кодексу України 